13. Clifford S. M., Murphy D. J. Non-alcoholic fatty liver disease and coronary atherosclerosis-does myocardial glucose metabolism provide the missing link? $J$ Nucl Cardiol. 2019. Vol. 14.

DOI: https://doi.org/10.1007/s12350-019-01783-z

14. Diabetes Atlas, 9th edn. / International Diabetes Federation (IDF). Brussels, Belgium: International Diabetes Federation. 2019. 176 p.

URL: https://www. diabetesatlas.org

15. Diabetes country profiles / World Health Organization. 2016. Ukraine. URL: http://www.who.int/diabetes/country-profiles/ukr_en.pdf?ua $=1$
16. EASL-EASD-EASO Clinical Practice Guidelines. J. Hepatol. 2016. Vol. 64, No. 6. P. 1388-1402. DOI: https://doi.org/10.1016/j.jhep.2015.11.004

17. Lean Americans With Nonalcoholic Fatty Liver Disease Have Lower Rates of Cirrhosis and Comorbid Diseases / E. M. Weinberg et al. Clin Gastroenterol Hepatol. 2020. Vol. 3. S1542-3565(20)30930-7. DOI: https://doi.org/10.1016/j.cgh.2020.06.066

18. Nonalcoholic fatty liver disease and mortality from all causes, cardiovascular disease, and cancer: a meta-analysis / Y. Liu et al. Sci Rep. 2019;9(1):11124. DOI: https://doi.org/10.1038/s41598-019-47687-3

The article was received 2020.10 .13

UDC 616.65-006-036.4-07-08

\title{
M.P. Melnychuk \\ CLINICAL SIGNIFICANCE OF HIGH GRADE AND LOW GRADE PROSTATE INTRAEPITHELIAL NEOPLASIA
}

State institution of science "Research and practical center of preventive and clinical medicine"

State administrative department

Verkhnia st., 5, Kyiv, 01014, Ukraine

ДНУ «Науково-практичний иентр профілактичної та клінічної медицини»

Державного управління справами

(дир. -д. мед. н. Д.Д. Дячук)

вул. Верхня, 5, Київ, 01014, Україна

e-mail: maksymmelnychuk1980@gmail.com

Цитування: Медичні перспективи. 2021. Т. 26, № 2. С. 134-140

Cited: Medicni perspektivi. 2021;26(2):134-140

Key words: high and low grade prostate intraepithelial neoplasia, prostate cancer, malignant transformation Ключові слова: простатична інтраепітеліальна неолазія високого та низького ступеня, рак простати, злоякісна трансформація

Ключевые слова: простатическая интраэпителиальная неоплазия высокой и низкой степени, рак простаты, злокачественная трансформация

Abstract. Clinical significance of high grade and low grade prostate intraepithelial neoplasia. Melnychuk M.P. Such premalignant conditions of prostate cancer (PC) as prostate intraepithelial neoplasia (PIN) are classified between benign and malignant ones. Contemporary evidence wheather PIN develops malignancy is limited and (LGPIN) data present varied results. Morphological and clinical differencies between high (HGPIN) and low grade PIN specimens in the prostate remain unclear. Aim of the work - to determine clinical significance and progression ability of high grade and low grade prostate intraepithelial neoplasia. The results of examination of 276 patients with PIN (152 patients with high grade PIN and 134 patients with low grade PIN) were assessed comparatively. During a 3 year follow-up repeated prostate biopsies were performed with 6 months interval to detect PC. Initial and repeated multifocal transrectal prostate biopsies from 12 samples were performed under transrectal ultrasonic guidance. There were statistically 
significant differences in PC detection rates between HGPIN and LGPIN. Patients with HGPIN had malignization rate of 42.1\% during a 3-year follow-up that was by 33.9\% higher than in LGPIN patients. The spread of HGPIN lesions within prostate gland is a malignization risk factor. The mean malignization term of HGPIN is 18 months and of LGPIN - 30 months. Low and high grade PIN are gradual stages of cancerogenesis. PIN grade determines its clinical significance, while LGPIN has low malignization potential, HGPIN possesses morphological and clinical prostate characteristics similar to adenocarcinima.

Реферат. Клінічне значення простатичної інтраепітеліальної неоплазії високого та низького ступеня. Мельничук М.П. Такий передпухлинний стан раку передміхурової залози (РПЗ), як простатична інтраепітеліальна неоплазія (ПІН), класифікується між доброякісними та злоякісними прочесами. На теперішній час кількість наукових даних про злоякісну прогресію ПІН недостатня та є дискутабельною. Залишаються нез'ясованими морфологічні та клінічні відмінності між ПІН високого та низького ступеня. Мета роботи визначити клінічне значення та здатність до прогресї простатичної інтраепітеліальної неоплазї високого та низького ступенів. До дослідження увійшли результати обстеження 276 пацієнтів з ПІН (152 хворих з ПІН високого ступеня та 134 хворих з ПІН низького ступеня). Впродовж 3-річного періоду спостереження виконувалися повторні біопсії простати з інтервалом 6 місяиів з метою виявлення РПЗ. Первинна та повторні трансректальні біопсії простати виконувалися під наведенням трансректального ультразвукового дослідження з 12 точок. Спостерігалася статистично достовірна різниця в частоті виявлення РПЗ між пацієнтами 3 ПІН високого та низького ступеня. Частота малігнізації в пацієнтів з ПІН високого ступеня становила 42, $1 \%$ впродовж 3-річного періоду спостереження та була на 33,9\% більшою, ніж у хворих з ПІН низького ступеня. Встановлено, щуо поширення осередків ПІН високого ступеня в простаті є фактором ризику малігнізації. Середній термін малігнізації при ПІН високого ступеня становив 18 місяців, а при ПІН низького ступеня - 30 місяиів. ПІН низького та високого ступеня є послідовними стадіями канцерогенезу. Ступінь ПІН визначає ї̈ клінічне значення. У той час, коли ПІН низького ступеня має низький потенціал злоякісної трансформації, ПІН високого ступеня має морфологічні та клінічні характеристики, схожі з аденокарциномою.

Prostate cancer (PC) occupies the second place in the structure of malignancies (after lung cancer) in men worldwide, counting 1,276,106 new cases and causing 358,989 deaths $(3.8 \%$ of all deaths caused by cancer in men) in 2018 [7].

Prostate intraepithelial neoplasia (PIN) which was described in 1969 [1] is a preneoplastic proliferation process of prostatic epithelium that is bounded to prostatic ducts or acini (glands). According to degree of pathological cellular changes, PIN is classified as low grade PIN (LGPIN) and high grade PIN (HGPIN). Despite numerous investigations the role of PIN in prostate cancerogenesis is being strongly discussed. There is abundant data supporting the statement that high-grade PIN (HGPIN) is a precursor lesion to adenocarcinoma of the prostate [9]. According to investigation data, HGPIN and PC have similar epidemiological and clinical features [16]. Like PC, the incidence of HGPIN dependes on age and is higher in AfricanAmerican men. HGPIN is more frequently detected in postoperative prostates along with PC than without it [18]. Also HGPIN is often multifocal and is located in the peripheral lateral part of the prostate gland [14]. HGPIN has similar to PC molecular and genetic changes that were investigated by researchers [5].

The incidence of high grade and low grade PIN is still under investigation. Despite the importance of recognizing PIN, there is still insufficient standardization in diagnostics methods and their description. There is large variability in reports of different pathologists due to subjectivity of diagnosis of PIN [13]. This variance depends on few peculiarities, such as type of specimen, preparation of tissue, selection of patients for biopsy [19]. Interobserver variability makes problematic the investigation of epidemiology and clinical diagnosis of prostate adenocarcinoma [10]. Tan et al reviewing "benign" needle core biopsies specimens demonstrated that $75 \%$ of HGPIN lesions were initially missed by reporting pathologists [2]. Moreover, Kronz et al discovered a 30-patient oversight of HGPIN out of 3251 prostate biopsies. According to data of researchers HGPIN formed $34.5 \%$ of the missed lesions identified in the study [6]. Because of lack of standardization in case of low-grade PIN, urologists do not routinely report this precancerous state, only for investigation aimes [11].

Clinical significance of PIN depends on its malignant potential and on its association with cancer which is detected on subsequent biopsies. Analysis of scientific works that were conducted before mid-1990s and assessed cancer risk on repeated prostate biopsies after diagnosis of isolated HGPIN demonstrated a great data variety - from $27 \%$ to $100 \%$. After the prevalent introduction of extended core biopsy techniques, it has been established that there is a lower risk of PC detection on repeated biopsies [1]. Lower incidence of prostate adenocarcinoma detection on repeated biopsies was connected with prostate screening programs using widespread prostate-specific antigen (PSA) and as a 
result in insignificant, small-volume cancer at diagnosis, and introduction of extended biopsy techniques with investigation of the peripheral lateral zone of the prostate gland [17].

The spread of PIN in prostate gland is assessed as a risk factor of malignization. To the opinion of Merrimen JL et al. the number of positive cores that contain HGPIN is the one pathological factor that predicts a higher risk of $\mathrm{PC}$ on repeated biopsy. The presence of multifocal high-grade PIN on prostate biopsy (involving 2 or more cores) represents a risk factor for detection of cancer on repeated biopsies [17]. HGPIN with 3 cores or more is associated with a sufficiently high risk of cancer and requires re-biopsy within a year of the initial PIN diagnosis. For cases with one or two cores of HGPIN on needle biopsy, it is recommended that men should not have a obligatory repeated needle biopsy during the first year after the diagnosis of HGPIN, in case of absence of other clinical and morphological risk factors of PC [12].

Although HGPIN is linked to PC, its malignant potential has been heavily debated. In fact, some studies discuss the fact of association of isolated HGPIN with a high risk of prostate adenocarcinoma on repeated biopsies $[5,10,11]$. Contemporary evidence regarding the etiology, natural history, surveillance, and management of PIN is limited. There is an abundance of compelling evidence to suggest that HGPIN is a precursor of PC. More studies with long follow-up period are needed to establish the role of high and low grade PIN in cancerogenesis of prostate.

The aim of the study was to investigate malignant transformation rates and clinical significance of high grade and low grade prostate intraepithelial neplasia.

\section{MATERIALS AND METHODS OF RESEARCH}

We studied 276 patients aged 48 to 76 years (mean age $65.6 \pm 1.4$ years) with PIN. All patients were divided into two groups according to PIN grade. The first group consisted of 152 patients with high grade PIN. The second research group consisted of 134 patients with low grade PIN. Diagnosis was confirmed morphologically after transrectal multifocal prostate biopsy that was performed according to PC suspicion. The methodics of prostate biopsy and morphological diagnosis were established according to European Association of Urology (EAU) Guidelines and Transrectal Ultrasound Guided Biopsy of the Prostate [3, 4] Within a 3 year follow-up there were performed prostate rebiopsies with 6 months' interval. The aim of rebiopsies was to assess morphological changes in prostate tissue and to detect PC. Initial and repeated transrectal prostate biopsies were performed under transrectal ultrasonic guidance with 12 samples.

Statistical analysis of the results was performed using "Statistica" (version 6.0, Statsoft Inc, USA. Licence AXXR712D833214FAN5) software. The significance of received results between groups was evaluated by Mann - Whitney test, $\mathrm{p}<0.05$ was considered as statistically significant [15].

\section{RESULTS AND DISCUSSION}

During a 3-years' follow-up in $75(27.2 \%)$ of 276 patients with PIN in repeated biopsies, PC was detected. The aim was to determine correlation between grade of PIN and rate of malignant transformation. PC was diagnosed in 64 $(42.1 \%)$ patients with HGPIN and in $11(8.2 \%)$ patients with LGPIN (Fig. 1).

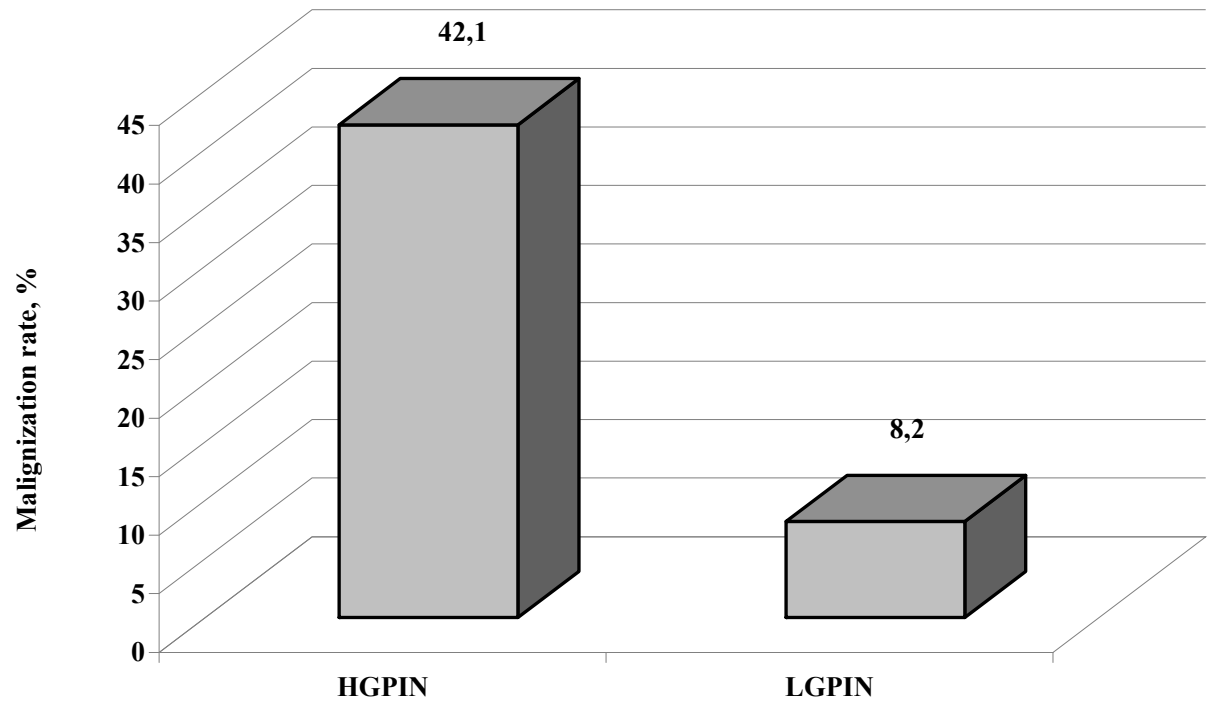

Fig. 1. Rate of malignization in patients with PIN 
To study correlation between malignization rate and spread of PIN lesions in prostate tissue all patients were devided into groups by number of PIN positive cores. 106 patients composed the first group who had 1-2 PIN samples, the second group (93 patients) - 3-4 samples, the third group (77 patients)
-5 and more samples. Analysis showed that PC was detected in $16(21.3 \%)$ of patients with 1-2 PIN lesions, in $23(30.7 \%)$ of patients with 3-4 PIN lesions and in $36(48 \%)$ of patients with 5 and more PIN lesions (Fig. 2).

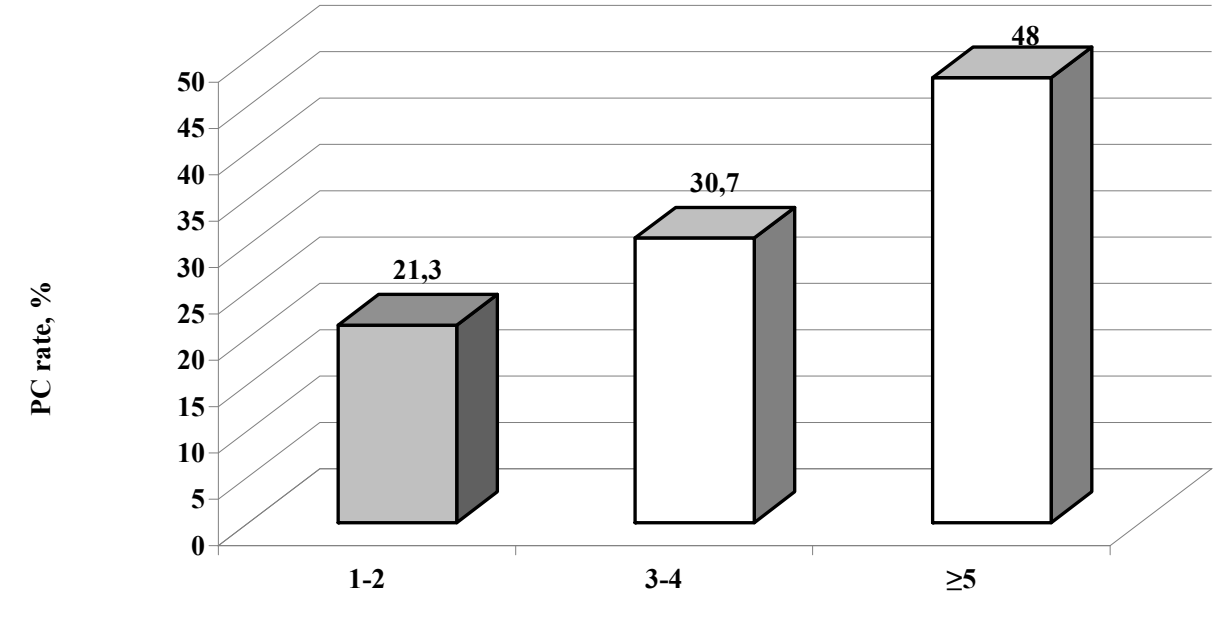

PIN cores number

Fig. 2. PC rate depending on number of PIN positive cores

Thus analysis of PIN spread in prostate tissue that was determined as a number of PIN positive biopsy samples established direct correlation between PIN spread and subsequent PC. Most frequently malignant transformation was observed in patients who had 5 and more PIN samples initially. In group with 3-4 PIN samples PC, was detected by $22.1 \%$ and in group with 1-2 PIN samples - by 31,7 less frequently.

The follow-up period was 3 years. The aim was to study the terms of high and low grade PIN malignant transformation and adenocarcinoma diagnostics. It was found that among $64 \mathrm{PC}$ cases in patients with HGPIN that were detected during 3year follow-up period in $28(43.8 \%)$ patients adenocarcinoma was diagnosed during the period from 12 months to 18 months, in $16(25 \%)$ patients from 6 to 12 months, in 11 (17.2\%) patients from 18 to 24 months, in $4(6.3 \%)$ from 24 to 30 months and from 30 to 36 months and in $1(1.6 \%)$ PC was diagnosed in 6 months after HGPIN diagnose.

Among 11 PC cases in patients with LGPIN that were detected during 3-year follow-up period in 5 (45.5\%) patients adenocarcinoma was diagnosed during the period from 24 to 30 months, in $3(27.3 \%)-$ from 30 to 36 months, in $2(18.2 \%)$ patients - from 18 to 24 months, in $1(9.1 \%)$ patients - from 12 to 18 months. During the first year after initial biopsy in patients with LGPIN, PC was not detected.

Thus obtained data evidence that the terms of PIN transformation into adenocarcinoma variate from 1 to 3 years. The difference was observed between median terms of HGPIN and LGPIN malignant transformation. In patients with HGPIN PC was diagnosed mainly during the period from 12 to 24 months (the second year follow-up), namely 39 $(60.9 \%)$ PC cases. Conversely, in patients with LGPIN the main amount of adenocarcinoma was detected later - during the period from 24 to 30 months, namely 5 (45.5\%) PC cases.

Clinical significance of precancerous disease is determined by its malignant transformation ability. Numerous investigations that were performed to make clear PIN malignization rate came to opposite conclusions because of different research methods, namely histological and statistical differences. Historically it is difficult to compare morphological data because a lot of researchers used different approaches to describe such premalignant states as high and low grade PIN, ASAP, intraductal carcinoma. Most studies were analized with insufficient material for reliable statistical assessment including data of prostate biopsies, transurethral prostate resection, autopsies. 


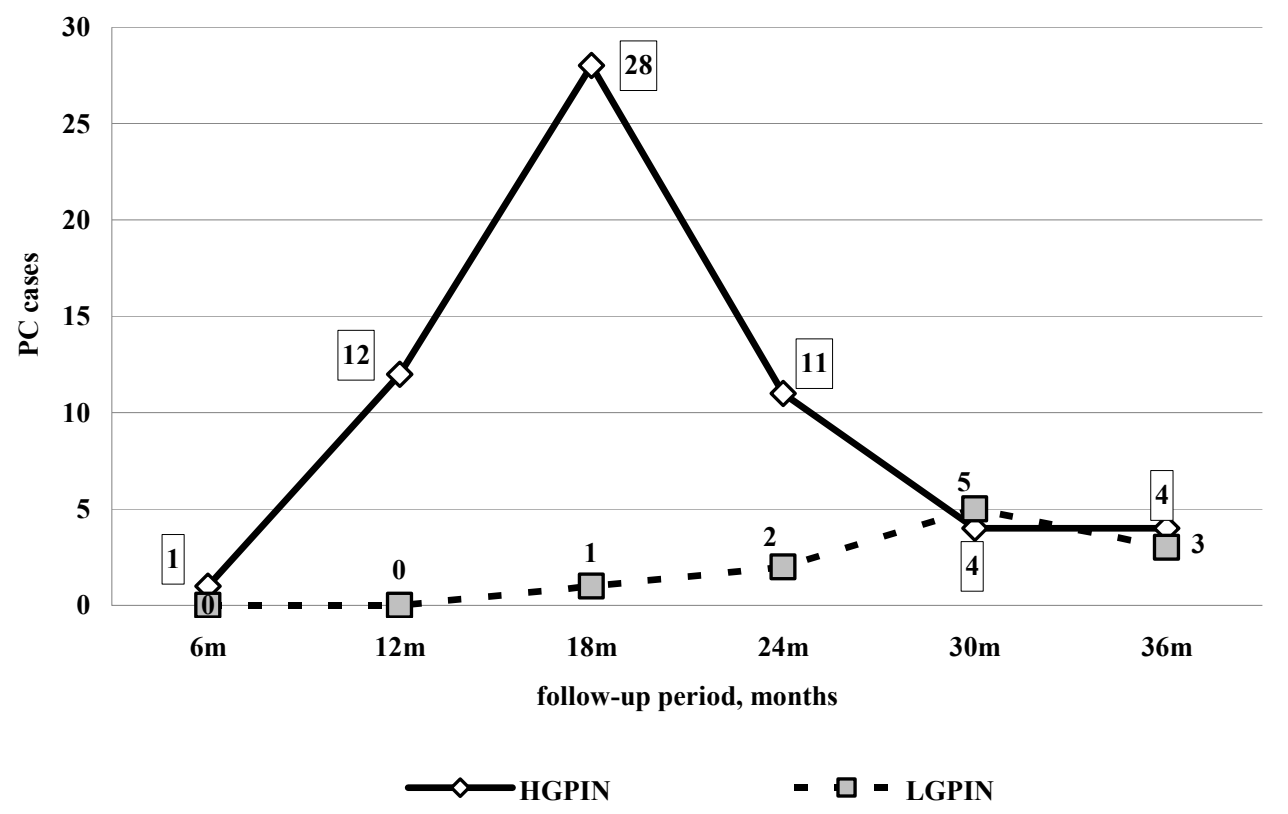

Fig. 3. PC detection in patients with PIN during 3 year follow-up

In our study we tried to follow last recommendations and classifications of premalignant prostate states and to use appropriate statistical methods. It was determined that clinical significance of PIN correlates with its grade. HGPIN is a precancerous pathology with malignization rate of $42.1 \%$ while follow-up of patients with LGPIN demonstrated insignificant malignization ability of $8.2 \%$. Obtained data correlate with those of De Marzo et al. [16]. Besides it was established that PC rate in patients with HGPIN depends on spread of PIN in prostate, namely on the number of positive samples. The highest risk of PC diagnose is in case of 5 and more PIN samples. Our data correlate with research work of Zhou M. et al. [8].

The terms of malignization differ in patients with high and low grade PIN. Our study showed that cancerogenesis is a gradual process that proceeds through sequenced stages from benign tissue through LGPIN to HGPIN and finally to prostate adenocarcinoma.

It is important to distinguish a group of high malignization risk among patients with PIN based on immunohistochemical investigation, PSA, MRI data. These patients need detailed precise examination and treatment to prevent malignant transformation in every individual case.

\section{CONCLUSIONS}

1. High grade prostate intraepithelial neoplasia is a prostate cancer precursor with high progression ability.
Malignization rate in patients with high grade prostate intraepithelial neoplasia amounted $42.1 \%$ during a 3year follow-up and was by $33.9 \%$ higher than in low grade prostate intraepithelial neoplasia patients.

2. Low grade prostate intraepithelial neoplasia should be considered an initial cancerogenesis process with mainly benign tissue features. Malignization rate in patients with low grade prostate intraepithelial neoplasia amounted 8.2\% during a 3year follow-up.

3. The spread (extent) of high grade prostate intraepithelial neoplasia lesions within prostate gland is a malignization risk factor. It was established a direct correlation between with prostate cancer rate and number of biopsy cores high grade prostate intraepithelial neoplasia positive samples prostate gland.

4. Low and high grade prostate intraepithelial neoplasia are gradual stages of cancerogenesis. The mean malignization term of high grade prostate intraepithelial neoplasia is 18 months and of low grade prostate intraepithelial neoplasia - 30 months.

5. Prostate intraepithelial neoplasia grade determines its clinical significance. While low grade prostate intraepithelial neoplasia has low malignization potential, high grade prostate intraepithelial neoplasia possesses morphological and clinical characteristics of adenocarcinima.

Conflict of interests. The authors declare no conflict of interest. 


\section{REFERENCES}

1. Bosland MC, Ozten N, Eskra JN, Mahmud AM. A perspective on prostate carcinogenesis and chemoprevention. Curr Pharm Rep. 2015;1:258-65. doi: https://doi.org/10.1007/s40495-015-0031-0

2. Testa U, Castelli G, Pelisi E. Cellular and Molecular Mechanisms Underlying Prostate Cancer Development: Therapeutic Implications. Medicines. 2019;82:8-26. doi: https://doi.org/10.3390/medicines6030082

3. Xue J, Qin Z, Cai H. Comparison between transrectal and transperineal prostate biopsy for detection of prostate cancer: a meta-analysis and trial sequential analysis. Oncotarget. 2017;8:23322-36.

doi: https://doi.org/10.18632/oncotarget.15056

4. Mottet N, Bellmunt J, Bolla M. EAU-ESTROSIOG Guidelines on Prostate Cancer. Part 1: Screening, Diagnosis, and Local Treatment with Curative Intent. Eur Urol. 2017;71:618-29.

doi: https://doi.org/10.1016/j.eururo.2016.08.003

5. Freitas GM, Andriole GL, Castro-Santamaria R. Extent of baseline prostate atrophy is associated with lower incidence of low and high-grade prostate cander on biopsy. Urology. 2017;103:161-6.

doi: https://doi.org/10.1016/j.urology.2016.12.027

6. Jung SH, Shin S, Kim MS. Genetic progression of high grade prostatic intraepithelial neoplasia to prostate cancer. Eur. Urol. 2016;69:823-30.

doi: https://doi.org/10.1016/j.eururo.2015.10.031

7. Bray F, Ferlay J, Soerjomataram I, Siegel RL. Global cancer statistics 2018: GLOBOCAN estimates of incidence and mortality worldwide for 36 cancers in 185 countries. CA Cancer J Clin. 2018;68(6):394-424. doi: https://doi.org/10.3322/caac.21492

8. Zhou M. High-grade prostatic intraepithelial neoplasia, PIN-like carcinoma, ductal carcinoma, and intraductal carcinoma of the prostate. Modern Pathology. 2018;31:7179. doi: https://doi.org/10.1038/modpathol.2017.138

9. Wiener S, Haddock P, Cusano J. Incidence of Clinically Significant Prostate Cancer After a Diagnosis of Atypical Small Acinar Proliferation, High-grade Prostatic Intraepithelial Neoplasia, or Benign Tissue. Urology. 2017;110:161-5.

doi: https://doi.org/10.1016/j.urology.2017.08.040

10. Najla A, Amer H, Nour A. Interobserver Variability in the Diagnosis of High-Grade Prostatic In- traepithelial Neoplasia in a Tertiary Hospital in Northern Jordan. Clinical Pathology. 2018;13:1-4. doi: https://doi.org/10.1177/2632010X19898472

11. Szentirmaj E, Giannico GA. Intraductal carcinoma of the prostate. Pathologia. 2020;112:17-24. doi: https://doi.org/10.32074/1591-951X-5-20

12. Tolkach Y, Kristiansen G. Is high-grade prostatic intraepithelial neoplasia (HGPIN) a reliable precursor for prostate carcinoma? Implications for clonal evolution and early detection strategies. The journal of pathology. 2018;244:389-93. doi: https://doi.org/10.1002/path.5045

13. Tosoian JJ, Alam R, Ball MW, Carter HB, Epstein JI. Managing high-grade prostatic intraepithelial neoplasia (HGPIN) and atypical glands on prostate biopsy. Nat Rev Urol. 2018;15(1):55-66. doi: https://doi.org/10.1038/nrurol.2017.134

14. Haffner MC, Barbieri CE. Shifting Paradigms for High-grade Prostatic Intraepithelial Neoplasia. Eur Urology. 2016;69:831-33.

doi: https://doi.org/10.1016/j.eururo.2015.11.020

15. Pukl M, Keyes S, Keyes M. Multi-scale tissue architecture analysis of favorable-risk prostate cancer: Correlation with biochemical recurrence. Investig Clin Urol. 2020;61(5):482-90.

doi: https://doi.org/10.4111/icu.20200018

16. De Marzo AM, Haffner MC, Lotan TL, et al. Premalignancy in prostate cancer: rethinking what we know. Cancer Prev Res (Phila) 2016;9:648-56. doi: https://doi.org/10.1158/1940-6207.CAPR-15-0431

17. Haffner MC, Weier C, Xu M. Molecular evidence that invasive adenocarcinoma can mimic prostatic intraepithelial neoplasia (PIN) and intraductal carcinoma through retrograde glandular colonization. J Pathol 2015;238:31-41. doi: https://doi.org/10.1002/path.4628

18. Fowke JH, Motley SS. Statin use linked with a decrease in the conversion from high-grade prostatic intraepithelial neoplasia (HGPIN) to prostate cancer. Carcinogenesis. 2018;28;39(6):819-25.

doi: https://doi.org/10.1093/carcin/bgy050

19. Xiao GQ, Golestani R, Pham H. Stratification of Atypical Intraepithelial Prostatic Lesions Based on Basal Cell and Architectural Patterns. American Journal of Clinical Pathology. 2019;153:407-16.

doi: https://doi.org/10.1093/ajcp/aqz183

\section{СПИСОК ЛІТЕРАТУРИ}

1. A perspective on prostate carcinogenesis and chemoprevention / M. C. Bosland et al. Curr Pharm Rep. 2015. Vol. 1. P. 258-265.

DOI: https://doi.org/10.1007/s40495-015-0031-0

2. Cellular and Molecular Mechanisms Underlying Prostate Cancer Development: Therapeutic Implications / U. Testa et al. Medicines. 2019. Vol. 82. P. 8-26. DOI: https://doi.org/10.3390/medicines6030082

3. Comparison between transrectal and transperineal prostate biopsy for detection of prostate cancer: a meta- analysis and trial sequential analysis / J. Xue et al. Oncotarget. 2017. Vol. 8. P. 23322-23336. DOI: https://doi.org/10.18632/oncotarget.15056

4. EAU-ESTRO-SIOG Guidelines on Prostate Cancer. Part 1: Screening, Diagnosis, and Local Treatment with Curative Intent / N. Mottet et al. Eur Urol. 2017. Vol. 71. P. 618-629.

DOI: https://doi.org/10.1016/j.eururo.2016.08.003

5. Extent of baseline prostate atrophy is associated with lower incidence of low and high-grade prostate 
cander on biopsy / G. M. Freitas et al. Urology. 2017. Vol. 103. P. 161-166.

DOI: https://doi.org/10.1016/j.urology.2016.12.027

6. Genetic progression of high grade prostatic intraepithelial neoplasia to prostate cancer / S. H. Jung et al. Eur. Urol. 2016. Vol. 69. P. 823-830. DOI: https://doi.org/10.1016/j.eururo.2015.10.031

7. Global cancer statistics 2018: GLOBOCAN estimates of incidence and mortality worldwide for 36 cancers in 185 countries / F. Bray et al. CA Cancer $J$ Clin. 2018. Vol. 68, No. 6. P. 394-424.

DOI: https://doi.org/10.3322/caac. 21492

8. High-grade prostatic intraepithelial neoplasia, PIN-like carcinoma, ductal carcinoma, and intraductal carcinoma of the prostate / M. Zhou et al. Modern Pathology. 2018. Vol.31. P. 71-79. DOI: https://doi.org/10.1038/modpathol.2017.138

9. Incidence of Clinically Significant Prostate Cancer After a Diagnosis of Atypical Small Acinar Proliferation, High-grade Prostatic Intraepithelial Neoplasia, or Benign Tissue / S. Wiener et al. Urology. 2017. Vol. 110. P. 161-165.

DOI: https://doi.org/10.1016/j.urology.2017.08.040

10. Interobserver Variability in the Diagnosis of High-Grade Prostatic Intraepithelial Neoplasia in a Tertiary Hospital in Northern Jordan / A. Najla et al. Clinical Pathology. 2018. Vol. 13. P. 1-4. DOI: https://doi.org/10.1177/2632010X19898472

11. Intraductal carcinoma of the prostate / E. Szentirmaj et al. Pathologia. 2020. Vol. 112. P. 17-24. DOI: https://doi.org/10.32074/1591-951X-5-20

12. Is high-grade prostatic intraepithelial neoplasia (HGPIN) a reliable precursor for prostate carcinoma? Implications for clonal evolution and early detection strategies / Y. Tolkach et al. The journal of pathology. 2018. Vol. 244. P. 389-393.

DOI: https://doi.org/10.1002/path.5045
13. Managing high-grade prostatic intraepithelial neoplasia (HGPIN) and atypical glands on prostate biopsy / J. J. Tosoian et al. Nat Rev Urol. 2018. Vol. 15, No. 1. P. 55-66. DOI: https://doi.org/10.1038/nrurol.2017.134

14. Molecular evidence that invasive adenocarcinoma can mimic prostatic intraepithelial neoplasia (PIN) and intraductal carcinoma through retrograde glandular colonization / M. C. Haffner et al. J Pathol. 2015. Vol. 238. P. 31-41.

DOI: https://doi.org/10.1002/path.4628

15. Multi-scale tissue architecture analysis of favorable-risk prostate cancer: Correlation with biochemical recurrence / M. Pukl et al. Investig Clin Urol. 2020. Vol. 61, No. 5. P. 482-490.

DOI: https://doi.org/10.4111/icu.20200018

16. Premalignancy in prostate cancer: rethinking what we know / A. M. De Marzo et al. Cancer Prev Res (Phila). 2016.Vol. 9. P. 648-656.

DOI: https://doi.org/10.1158/1940-6207.CAPR-15-0431

17. Shifting Paradigms for High-grade Prostatic Intraepithelial Neoplasia. / M. C. Haffner et al. Eur Urology. 2016. Vol. 69. P. 831-833.

DOI: https://doi.org/10.1016/j.eururo.2015.11.020

18. Statin use linked with a decrease in the conversion from high-grade prostatic intraepithelial neoplasia (HGPIN) to prostate cancer / J. H. Fowke et al. Carcinogenesis. 2018. Vol. 39, No. 6. P. 819-825. DOI: https://doi.org/10.1093/carcin/bgy050

19. Stratification of Atypical Intraepithelial Prostatic Lesions Based on Basal Cell and Architectural Patterns. / G. Q. Xiao et al. American Journal of Clinical Pathology. 2019. Vol. 153. P. 407-416.

DOI: https://doi.org/10.1093/ajcp/aqz183

The article was received 2020.09 .28 